\title{
First report of Alternaria alternata causing black spot on pink lapacho (Handroanthus impetiginosus)
}

\author{
G. Dal Bello • E. Franco • S. Larrán • P. Balatti
}

Received: 19 May 2014 / Accepted: 19 January 2015 / Published online: 1 February 2015

(C) Australasian Plant Pathology Society Inc. 2015

\begin{abstract}
A severe leaf spot disease was observed on pink lapacho trees, Handroanthus impetiginosus for the first time in Buenos Aires province, Argentina during the autumn of 2013. The pathogen was identified as Alternaria alternata based on the morphological characteristics and sequence data from the internal transcribed spacer region of ribosomal DNA, and partial $\beta$-tubulin sequence. A pathogenicity test was performed and Koch's postulates were confirmed by re-isolating the fungus from artificially inoculated leaves. This is the first report of Alternaria black spot of Handroanthus impetiginosus trees.
\end{abstract}

Keywords Lapacho Alternaria alternata ITS bar code . Leaf spot

Handroanthus impetiginosus (common name pink lapacho, pau d'arco or taheebo), syn. Tabebuia impetiginosa, family Bignoniaceae, is a native tree of America. It grows from northern Mexico to northern Argentina and is a member of tropical rain forests throughout Central and South America. In South America and Europe, this blooming tree is used as an ornamental plant in landscaped gardens and public areas. It produces high-quality wood that is used to build houses, boats and/or farm tools. Traditionally the inner bark of $H$. impetiginosus has ethnopharmacological applications like the treatment of skin

G. Dal Bello $(\bowtie) \cdot$ E. Franco $\cdot$ S. Larrán $\cdot$ P. Balatti

Centro de Investigaciones de Fitopatología (CIDEFI), Facultad de

Ciencias Agrarias y Forestales, Universidad Nacional de La Plata, 60

y 119, La Plata 1900, Buenos Aires, Argentina

e-mail: dalbello@speedy.com.ar

G. Dal Bello $\cdot$ P. Balatti

Comisión de Investigaciones Científicas de la Provincia de Buenos

Aires (CICBA), La Plata, Buenos Aires, Argentina inflammatory diseases such as eczema, psoriasis, bacterial infections and even human cancers (Woo and Choi 2005; Kim et al. 2007; Byeon et al. 2008). During autumn of 2013, leaves of lapachos growing in the urban area of La Plata (Middle eastern, Argentina, Buenos Aires province) presented many spots that looked like disease symptoms (Fig. 1). Both leaf surfaces presented large necrotic lesions, of a brown-to-black colour that increased their size, became irregular and eventually coalesced resulting in withering, extensive drying and shedding of leaves.

Pieces of Infected leaf tissue were surface sterilized with $1 \% \mathrm{NaOCl}$ solution for $1 \mathrm{~min}$ and plated on potato dextrose agar (PDA) that were incubated at $25{ }^{\circ} \mathrm{C}$ for 7 days under a $12 \mathrm{~h}$ light photoperiod. Within 7 days of incubation, white fungal colonies developed which initially turned to green olivaceous colour and later turned to black as the culture aged. Conidiophores were short, septate, branched or unbranched, and had a golden brown appearance, measuring $15 \mu \mathrm{m}$ long and 2-6 $\mu \mathrm{m}$ thick. Conidia were obclavate, obpyriform or ellipsoidal with a short conical beak, and borne in long chains, pale brown to golden brown in colour, measuring 19-39 $\mu \mathrm{m}$ long and 6-15 $\mu \mathrm{m}$ wide at the broadest point, showing 2-5 transverse septa. Based on the described morphological characters, the pathogen was tentatively identified as Alternaria alternata (Fr.) Keissler (Simmons 2007). This identification was confirmed by molecular data from partial $\beta$-tubulin and Internal Transcribed Spacer (ITS) (International Bar Code, Schoch et al. 2012). Genomic DNA of pure cultures was isolated by means of the Wizard ${ }^{\circledR}$ Genomic DNA Purification Kit (Promega, Madison, WI) according to manufacturer's instruction. The ITS was amplified using ITS-4 and ITS-5 primers (White et al. 1990) and the partial $\beta$-tubulin sequence using Bt1a and Bt1b primers (Glass and Donaldson 1995). Both reactions were performed in a $15 \mu \mathrm{L}$ final volume containing $50 \mathrm{ng}$ of template DNA, $50 \mathrm{ng}$ of each forward and reverse primer, $1.5 \mu \mathrm{L} 10 \times$ 


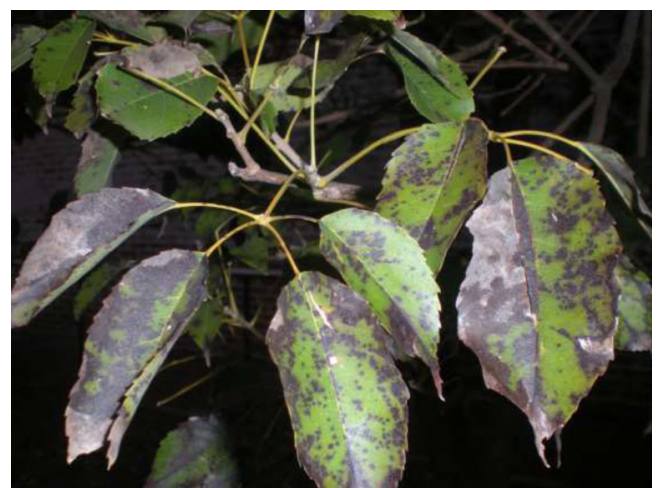

Fig. 1 Alternaria black spots of pink lapacho leaves caused by A. alternata

reaction buffer, $1.5 \mathrm{mM} \mathrm{MgCl} 2,0.2 \mathrm{mM}$ dNTPs and 0.5 unit Taq polymerase (all Inbio Highway ${ }^{\circledR}$, Buenos Aires, Argentina). Amplifications were done in a PTC-0150 MiniCycler (MJ Research. Watertown, MA, USA) programmed as follows: an initial denaturation step of $4 \mathrm{~min}$ at $94{ }^{\circ} \mathrm{C}$, followed by 33 cycles of $1 \mathrm{~min}$ at $94{ }^{\circ} \mathrm{C}, 45 \mathrm{~s}$ at $56{ }^{\circ} \mathrm{C}$ for ITS and at $58{ }^{\circ} \mathrm{C}$ for $\beta$-tubulin, $1 \mathrm{~min}$ at $72{ }^{\circ} \mathrm{C}$, with a final elongation of $7 \mathrm{~min}$. The amplicons obtained were purified and sequenced as described by Sanger et al. (1977) using the same set of primers. The 570 bp ITS sequence (GenBank accession $\mathrm{N}^{\circ}$ KJ829533) and the 422 bp $\beta$-tubulin sequence (GenBank accession $N^{\circ}$ KM396706) were $100 \%$ homologous to those of Alternaria alternata epitype CBS916.96 (GenBank accession $\mathrm{N}^{\circ}$ FJ196306) and KS53-2 (GenBank accession $\mathrm{N}^{\circ}$ KJ008699), the etiological agent of leaf spot of jujube in Xinjiang, China. Pathogenicity of the isolate was determined as described by Belisario et al. (1999). Three cultures of siblings isolated from leaves with similar symptoms were grown on PDA for 2 weeks. Leaflets were then inoculated with $5 \mu \mathrm{l}$ of a $1 \times 10^{5}$ spore suspension obtained from the culture. A total of 25 leaflets were inoculated. The leaves were then placed in petri dishes with a wet, sterilized piece of cotton, and incubated at $25{ }^{\circ} \mathrm{C}$ in the dark $(90 \%$ relative humidity and a $12-\mathrm{h}$ photoperiod). After 7 days, spots similar to symptoms of the disease developed (Fig. 2) and A. alternata was consistently re-isolated from the diseased tissues. Control leaves mock inoculated with sterile distilled water remained asymptomatic. The pathogenicity test was repeated three times and the results were similar. A culture of the isolate used in pathogenicity and taxonomic studies was deposited in the Culture Collection of the Centro de Investigaciones de Fitopatología (CIDEFI), Facultad de Ciencias Agrarias y Forestales, University of La Plata as CIDEFI AA124. Alternaria alternata has been reported on Handroanthus from Brazil on H. serratifolia (as Tabebuia serratifolia) (Farr and Rossman 2014), and

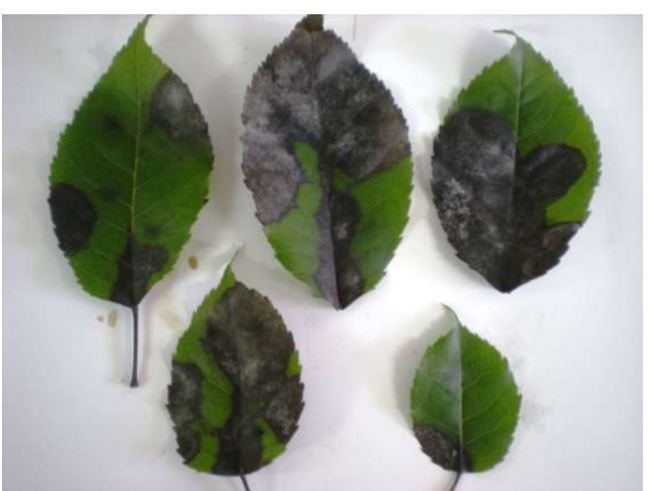

Fig. 2 Detached leaf inoculation test with pathogenic (black spot) A. alternata isolates

seedlings of Handroanthus sp. (as Tabebuia sp.) in Mexico (Tovar et al. 2008). To the best of our knowledge this is the first report of $A$. alternata causing leaf spot on $H$. impetiginosus trees.

\section{References}

Belisario A, Forti E, Corazza L, Van Kesteren HA (1999) First report of Alternaria alternata causing leaf spot on English walnut. Plant Dis 83:696

Byeon SE, Chung JY, Lee YG, Kim BH, Kim KH, Cho JY (2008) In vitro and in vivo anti-inflammatory effects of taheebo, a water extract from the inner bark of Tabebuia avellanedae. J Ethnopharmacol 119:145-152

Farr DF, Rossman AY (2014) Fungal databases, systematic mycology and microbiology laboratory, ARS, USDA. Retrieved April 13, 2014, from http://nt.ars-grin.gov/fungaldatabases/

Glass NL, Donaldson GC (1995) Development of primer sets designed for use with the PCR to amplify conserved genes from filamentous ascomycetes. Appl Environ Microbiol 4:1323-1330

Kim SO, Kwon JI, Jeong YK, Kim GY, Kim ND, Choi YH (2007) Induction of Egr-1 is associated with anti-metastatic and antiinvasive ability of beta-lapachone in human hepatocarcinoma cells. Biosci Biotechnol Biochem 7:2169-2176

Sanger F, Nicklen S, Coulson AR (1977) DNA sequencing with chainterminating inhibitors. Proc Natl Acad Sci U S A 74:5463-5467

Schoch CL, Seifert KA, Huhndorf S, Robert V, Spouge JL, Levesque CA, Chen W, Fungal Barcoding Consortium (2012) Nuclear ribosomal internal transcribed spacer (ITS) region as a universal DNA barcode marker for Fungi. Proc Natl Acad Sci U S A 109:6241-6246

Simmons EG (2007) Alternaria: an 1dentification manual. CBS Fungal Biodiversity Centre, Utrecht, p 775

Tovar DC, García Díaz S, Don Juan Macías B (2008) Manual Identificación y manejo de plagas y enfermedades en viveros forestales. Edición: Leticia Arango Caballero. Comisión Nacional Forestal. D.F, México, p 76

White TJ, Bruns T, Lee S, Taylor J (1990) Amplification and direct sequencing of fungal ribosomal RNA genes for phylogenetics. In: Innis MA, Gelfand DH, Sninsky JJ, White TJ (eds) PCR protocols. A guide to methods and applications. Academis press, San Diego, pp 315-322

Woo HJ, Choi YH (2005) Growth inhibition of A549 human lung carcinoma cells by beta-lapachone through induction of apoptosis and inhibition of telomerase activity. Int J Oncol 26:1017-1023 